\title{
MANAJEMEN PEMBELAJARAN TAHSIN AL-QURAN BERBASIS METODE TILAWATI
}

\section{Heri Khoiruddin}

Universitas Islam Negeri Sunan Gunung Djati Bandung

Email: herikhoiruddin@uinsgd.ac.id

\section{Adjeng Widya Kustiani}

Universitas Islam Negeri Sunan Gunung Djati Bandung

Email: adjengwidya1@gmail.com

\begin{abstract}
ABSTRAK
SD Istiqamah Kota Bandung merupakan yayasan sekolah yang memiliki konsep Islami dengan memfokuskan terhadap pembelajaran Al-Quran, hal yang menjadi permasalahan dalam pembelajaran Tahsin Al-Quran tersebut siswa merasa bosan dan kurang bersemangat. Tetapi dengan merubahnya metode yang digunakan dengan metode tilawati siswa memiliki kemajuan dalam pembelajaran Tahsin Al-Quran tersebut. Tujuan penelitian ini adalah untuk mengetahui hasil yang dicapai dalam manajemen pembelajaran Tahsin Al-Quran di SD Istiqamah Kota Bandung. Penelitian ini menggunakan metode peneltian deskriptif kualitatif dan teknik pengumpulan data melalui wawancara, observasi dan teknik studi dokumentasi. Manajemen pembelajaran Tahsin Al-Quran dilakukan mulai perencanaan, pelaksanaan dan penilaian sehingga pembelajaran Tahsin AlQuran berjalan secara efektif dan efisien. Peningkatan kualitas pendidik, sarana dan prasarana pun terus dilakukan di SD Istiqamah Kota Bandung. Sehingga menghasilkan siswa yang lancar dalam bacaannya serta bisa melanjutkan ketahap Tahfidz Al-Quran dan menyelesaikannya sebanyak 2 juz.
\end{abstract}

Kata Kunci: Manajemen, Pembelajaran, Tahsin al-Quran

\section{ABSTRACT}

Istiqamah Elementary School in Bandung City is a school foundation that has an Islamic concept by focusing on learning the Al-Quran, which is a problem in learning Tahsin Al-Quran that students feel bored and lack enthusiasm. But by changing the method used with the tilawati method students have progress in learning the Tahsin Al-Quran. The purpose of this study was to find out the results achieved in Tahsin Al-Quran learning management at Istiqamah Elementary School in Bandung City. This study uses descriptive qualitative research methods and data collection techniques through interviews, observation and documentation study techniques. Tahsin Al-Quran learning management is 
carried out starting from planning, implementation and assessment so that the AlQuran learning process runs effectively and efficiently. The binding of the quality of educators, facilities and infrastructure continues at Istiqamah Elementary School in Bandung City. So as to produce students who are fluent in their reading and can continue to the stage of Tahfidz Al-Quran and complete it as much as 2 juz.

Key words: management, learning, tahsin al-quran

\section{PENDAHULUAN}

Pendidikan Islam adalah upaya mengembangkan, mendorong serta mengajak manusia untuk lebih maju berlandaskan nilai-nilai yang tinggi dan kehidupan yang mulia, sehingga terbentuk pribadi yang berakhlak sempurna. Hal ini sesuai dengan tujuan Pendidikan Nasional. Sebagaimana diamanahkan dalam Undang-Undang Nomor 20 Tahun 2003 tentang Sistem Pendidikan Nasional Bab II Pasal 3 dan Pasal 30 ayat 2 dan 3 bahwa pendidikan nasional berfungsi mengembangkan kemampuan dan membentuk watak serta peradaban bangsa yang bermartabat dalam rangka mencerdaskan kehidupan bangsa, bertujuan untuk mengembangkan potensi siswa agar menjadi manusia yang beriman dan bertakwa kepada Tuhan Yang Maha Esa, berakhlak mulia, sehat, berilmu, cakap, kreatif, mandiri dan menjadi warga negara yang demokratis serta bertanggung jawab.

Secara umum tujuan pendidikan nasional adalah mencerdaskan kehidupan bangsa, mengembangkan konsep manusia seutuhnya dan konsep manusia yang bermoral religius, berbudi pekerti luhur, berpengetahuan, cakap, sehat, dan sadar sebagai warga negara. Tujuan pendidikan nasional didukung oleh tujuan setiap komponen pendidikan. Tiap komponen dalam sistem pendidikan nasional memberikan sumbangan terhadap pencapaian tujuan pendidikan nasional (Triwiyanto, 2015, hlm. 3).

Tiap komponen tersebut terwujud dalam sistem pendidikan nasional. Kurikulum dan pembelajaran merupakan komponen pendidikan yang sangat strategis karena merupakan seperangkat rencana dan pengaturan mengenai tujuan, isi, dan bahan pelajaran, serta cara yang digunakan sebagai pedoman yang diselenggarakan kegiatan pembelajaran untuk mencapai tujuan pendidikan tertentu. Komponen-komponen pendidikan merupakan penentu terhadap kalitas pendidikan (Triwiyanto, 2015, hlm. 3).

Salah satu pencapaian komponen pembelajaran tersebut yaitu dengan tercapainya tujuan pendidikan melalui pembelajaran Al-Quran yaitu dengan menerapkan pembelajaran Tahsin Al-Quran di Sekolah Dasar. Sebagai penerapan moral religius sejak dini siswa diajarkan dari dasar tata cara membaca dan melafalkan Al-Quran dengan baik dan benar. Sekarang banyak sekolah yang memiliki program pembelajaran Tahsin Al-Quran dengan menggunakan beberapa metode yang mudah dipahami oleh siswa, salah satunya yaitu menggunakan metode tilawati.

Pembelajaran memiliki hakikat perencanaan atau perancangan (desain) sebagai upaya untuk membelajarkan siswa. Itulah sebabnya dalam belajar, siswa tidak hanya berinteraksi dengan keseluruhan sumber belajar yang dipakai untuk mencapai tujuan pembelajaran yang diinginkan. Oleh karena itu, 
pembelajaran memusatkan perhatian pada bagaimana membelajarkan siswa, dan bukan pada apa yang dipelajari siswa. Pemilihan, penetapan dan pengembangan metode ini dari perencanaan pembelajaran (Uno, 2012, hlm. 2).

Tahsin merupakan cara membaca Al-Quran dengan baik dan benar dengan menggunakan kaidah-kaidah yang terdapat dalam ilmu tajwid, di samping memperbagus dan memperbaiki bacaan (Ariani \& Realita, 2015, hlm. 118). Al-Quran merupakan Undang-Undang yang abadi untuk kemaslahatan umat manusia, syari'at samawi untuk menjadi pedoman yang terbesar, benteng pertahanan syari'at Islam yang utama serta merupakan landasan sentral bagi tegaknya aqidah, mu'amalah dan akhlakul karimah. Dengan kata lain, Al-Quran merupakan satu-satunya alternatif yang dapat menjamin terciptanya kemaslahatan hidup serta azas untuk memperoleh kebahagiaan hidup di dunia dan di akhirat (Baharuddin, 2012, hlm. 63).

Pembelajaran Tahsin AI-Quran dilakukan di SD Istiqamah Kota Bandung berdasarkan klasifikasi kemampuan siswa. Dalam satu kelasnya siswa diajarkan sesuai dengan tingkat kemampuan dan kesulitan siswa. Kelas 1-4 dikhususkan untuk mempelajari Tahsin Al-Quran sedangkan untuk kelas 5 dan 6 itu dikhususkan untuk mempelajari Tahfidz Al-Quran juz 30. Bagi siswa yang berkemampuan diatas rata-rata itu bisa langsung dimasukan ke kelas Tahfidz AlQuran. Pembelajaran Tahsin AI-Quran di SD Istiqamah Kota Bandung dilakukan setiap hari Senin-Rabu, akan tetapi dalam seminggu sekali diadakannya ekstrakurikuler Tahfidz AI-Quran pada hari Kamis tujuannya untuk menunjang dari kelas rendah bawah belajar Tahfidz Al-Quran.

Ragam metode pembelajaran Tahsin dan Tahfidz Al-Quran di SD Istiqamah Kota Bandung yaitu dengan menggunakan 7 metode diantaranya: 1) metode talqin; 2) metode baca 10 kali; 3) metode yaqro; 4) metode alat bantu; 5) metode laugun; 6) metode afektif; dan 7) metode tilawati. Semua metode tersebut mencakup pada metode tilawati. Metode pembelajaran AI-Quran di SD Istiqamah Kota Bandung yaitu dengan menerapkan metode tilawati disemua kelas dari kelas 1 sampai kelas 6 .

Awal mula berkembangnya metode tilawati di SD Istiqamah Kota Bandung pada tahun 2014 yaitu dari metode iqra, seiring berjalannya waktu dengan diterapkannya metode iqra di SD Istiqamah Kota Bandung kurang begitu efektif dalam proses pembelajarannya. Pertama, menggunakan metode iqra cukup lama dalam pembelajaran Al-Quran nya. Kedua, dari segi pembelajarannya masih klasikal. Maka dari itu menggunakan metode iqro siswa merasa jenuh dan bosan ketika belajar mengajar Al-Quran berlangsung. Saat itulah pihak SD Istiqamah Kota Bandung melakukan studi banding ke SD Lukman Al-Hakim di Yogyakarta. SD Lukman Al-Hakim menerapkan metode tilawati dalam pembelajaran Tahsin Al-Quran. Dan hasilnya cukup maksimal siswa bisa dengan mudah memahami bacaan Al-Quran dengan baik dan benar menggunakan nada rost. Dari situlah SD Istiqamah Kota Bandung memiliki keinginan untuk mempelajari dan memperdalam metode tersebut untuk diterapkan dalam pembelajaran Tahsin AI-Quran di SD Istiqamah Kota Bandung. Pada waktu itu langsung menghubungi koordinator metode tilawati Bandung yaitu Ustad Kodar untuk izin menerapkan metode tilawati di SD Istiqamah Kota Bandung. Setelah satu tahun diterapkannya metode tilawati di SD Istiqamah Kota Bandung, siswa merasa lebih mudah dan cepat paham dalam pembelajaran Tahsin Al-Quran 
dengan metode tersebut. Akhirnya metode tilawati digunakan hingga saat ini di SD Istiqamah Kota Bandung.

Metode tilawati merupakan metode dasar dan mudah dipahami yang digunakan dalam tahsin AI-Quran. SD Istiqamah Kota Bandung mengajarkan metode tilawati kepada siswa sesuai dengan kemampuannya. Siswa bisa lebih mudah dalam mengikuti dan memahami bacaan Al-Quran. Yang menjadi pembeda dengan metode lainnya metode tilawati ini terdapat klasikal dan privat (baca simak). Tiga tehnik yang digunakan yaitu guru membaca siswa mendengarkan, guru membaca siswa menirukan dan guru membaca siswa pun membaca. Selain itu buku tajwid dan buku waqaf menjadi bahan acuan belajar siswa agar lebih mudah dan lebih memahami pembelajaran Al-Quran yang disampaikan. Dan di akhir pembelajaran diadakannya munaqosah sebagai bahan penilaian sekaligus evaluasi siswa.

\section{METODE}

Pendekatan penelitian yang dilakukan adalah pendekatan kualitatif. Jenis data yang digunakan adalah jenis kualitatif, yaitu data deskriptif berupa kata-kata tertulis atau lisan dari orang-orang dan perilaku yang dapat diambil. Pada penelitian kali ini peneliti memilih lokasi penelitian pembelajaran Tahsin AI-Quran di SD Istiqamaah Kota Bandung yang beralamat di Jalan Taman Citarum Kecamatan Bandung Wetan Kota Bandung Jawa Barat. Alasan pemilihan lokasi sebagai tempat penelitian karena diantaranya yaitu karena termotivasi untuk meneliti tentang manajemen pembelajaran Tahsin Al-Quran berbasis metode tilawati di SD Istiqamah Kota Bandung yang telah menerapkannya, kemudian SD Istiqamah Kota Bandung juga merupakan Yayasan Pendidikan Islam yang telah terakreditasi A, dan pihak lembaga yang diteliti yakni pembelajaran Tahsin AlQuran berbasis metode tilawati di SD Istiqamah Kota Bandung. Teknik pengumpulan datanya yaitu melalui wawancara, observasi dan menyalin dokumen. Teknik analisis data terdiri dari beberapa langkah, diantaranya yaitu unitisasi, kategorisasi data, dan penafsiran data.

\section{HASIL DAN PEMBAHASAN}

Pendidikan tidak akan terwujud tanpa adanya kerjasama satu sama lain yang saling berhubungan sehingga membentuk satu kesatuan (sistem). Maka dari itu pendidikan harus tersusun dan direncakan, sehingga sistem tersebut dapat berjalan dengan baik. Pengelolaan kegiatan pendidikan tersebut dikenal dengan istilah manajemen (Suryana dkk., 2019).

Manajemen merupakan disiplin ilmu yang bertugas mencari kebenaran dalam predikat dimensi teoritis dan metodologi yang harus diuji dan dibuktikan berdasarkan fakta/data secara objektif kebenarannya (Badrudin, 2013, hlm. 2). Manajemen adalah suatu proses yang khas terdiri atas tindakan-tindakan berupa perencanaan, pengorganisasian, penggerakan, dan pengendalian yang dilaksanakan untuk menentukan serta mencapai sarana-sarana atau tujuan yang telah ditentukan melalui pemanfaatan sumber daya manusia dan sumber-sumber lainnya (Jahari, 2013, hlm. 2).

Pembelajaran dipandang sebagai upaya maksimal yang dilakukan oleh guru dalam mempengaruhi siswa agar mau meningkatkan kegiatan belajarnya demi mencapai tujuan pembelajaran dengan efektif dan efisien (Haerana, 2016). 
Pembelajaran adalah suatu kegiatan yang dilakukan oleh guru sedemikian rupa, sehingga tingkah laku siswa berubah kearah yang lebih baik (Thomas, 2011, hlm. 17).

Pengertian manajemen pembelajaran demikian dapat diartikan secara luas, dalam arti mencakup keseluruhan kegiatan bagaimana membelajarkan siswa mulai dari perencanaan pembelajaran sampai pada penilaiannya. Pendapat lain menyatakan bahwa manajemen pembelajaran merupakan bagian dari strategi pengelolaan pembelajaran. Dengan berpijak dari pernyataanpernyataan terkait definisi manajemen pembelajaran tersebut, maka dapat dibedakan antara pengertian manajemen pembelajaran dalam arti luas dan manajemen pembelajaran dalam arti sempit. Dalam arti luas, manajemen pembelajaran adalah serangkaian proses kegiatan mengelola bagaimana membelajarkan siswa dengan diawali dengan kegiatan perencanaan, pengorganisasian, pengarahan atau pengendalian, dan penilaian. Sedangkan manajemen pembelajaran dalam arti sempit diartikan sebagai kegiatan yang perlu dikelola pendidik selama terjadinya interaksi dengan siswa dalam pelaksanaan pembelajaran (Badrudin, 2017, hlm. 159-160).

Menurut Abdullah tentang pembelajaran Al-Quran bahwa dalam pembelajaran Al-Quran ada sedikit perbedaan dengan pembelajaran bidang studi pada umumnya. Pola pembelajaran Al-Quran biasanya memakai bentuk halaqoh/kelompok kecil/micro teaching dalam aktivitas belajarnya, namun saat ini, pembelajaran dalam bentuk halaqoh masih dianggap sesuatu yang masih asing dan sulit, bahkan mungkin ada dari sebagaian pendidik, tidak terbayang dengan konsep halaqoh ini, karena konsep belajar yang mereka terima selama ini pada anak-anak pra sekolah dan sekolah dasar lebih banyak dengan pendekatan bermain atau dengan istilah 'learning by doing', sehingga yang tergambar dalam pikiran mereka, bahwa anak baru dapat belajar dengan baik dan menyenangkan kecuali sambil bermain, disamping itu bermain yang diiringi perasaan senang dianggap akan mampu mengembangkan kemampuan otak kanan dan otak kirinya (Supiani dkk., 2016, hlm. 42).

Perencanaan merupakan proses pendefinisian tujuan dan bagaimana untuk mencapainya sedangkan perencanaan dalam pembelajaran berarti menentukan tujuan, aktifitas dan hasil yang ingin dicapai dalam proses pembelajaran (Mahmuddin, 2013). Perencanaan merupakan penetapan pekerjaan yang harus dilaksanakaan oleh kelompok untuk mencapi tujuan yang digariskan. Perencanaaan mencakup kegiatan pengambilan keputusan, karena termasuk pemilihan alternatif-alternatif keputusan. Diperlukan kemampuan untuk mengadakan visualisasi dan meihat guna merumuskan suatu pola dari himpunan tindakan untuk masa mendatang (Terry, 2013, hlm. 17).

Perencanaan pembelajaran Tahsin AI-Quran di SD Istiqamah Kota Bandung dibuat dalam konsep umum yang dirumuskan dalam jangka pendek, menengah, dan panjang. Disusun pula kompetensi dasar yang harus dipenuhi oleh siswa dan strategi yang dikembangkan oleh guru untuk mencapai tujuan tersebut. Konsep ini disusun oleh kepala sekolah dan koordinator Tahsin AlQuran metode tilawati SD Istiqamah Kota Bandung. Rumusan konsep tersebut dibagi kedalam 5 jilid buku tilawati yaitu: pertama, dalam tilawati jilid 1 siswa mampu membaca huruf hijaiyah berharokat fathah berangkai baik sambung maupun tidak dengan bacaan lancar satu ketukan. Kedua, dalam tilawati jilid 2 
siswa lancar membaca kalimat berharokat kasroh, fathahtain, dhummahtain, kasrohtain dengan benar dan siswa lancar membaca bacaan panjang dan pendek 2 harokat ( $m a d)$. Ketiga, dalam tilawati jilid 3 siswa mampu membaca huruf-huruf sukun dengan sempurna tanpa ada kesalahan seperti tawallud dan saktah. Siswa tartil dan fasih membaca menggunakan irama rost. Keempat, dalam tilawati jilid 4 siswa menguasai praktek bacaan waqof, ghunnah (mendengung), harful muqotto'ah, mad wajib dan mad jaiz. Siswa tartil dan fasih membaca menggunakan irama rost. Kelima, dalam tilawati jilid 5 siswa menguasai praktek bacaan idhgom bigunnah dan bilaghunnah, qolqolah, iqlab, ikhfa syafawi dan idhar. Siswa tartil dan fasih membaca menggunakan irama rost. Setelah lulus dalam pembelajaran tahsin Al-Quran siswa dilanjutkan ke Tahfidz Al-Quran.

Setelah adanya rencana secara umum, maka dibutuhkan perencanaan proses pembelajaran. Perencanaan proses pembelajaran yang baik meliputi silabus dan Rencana Pelaksanaan Pembelajaran (RPP) yang memuat identitas mata pelajaran, Standar Kompetensi (SK), Kompetensi Dasar (KD), indikator pencapaian kompetensi, tujuan pembelajaran, materi ajar, alokasi waktu, metode pembelajaran, kegiatan pembelajaran, penilaian hasil belajar, dan sumber belajar (Nurkarima, 2015, hlm. 165).

SD Istiqamah Kota Bandung memiliki silabus dan Rencana Pelaksanaan Pembelajaran (RPP). Hanya saja komponen silabus dan RPP tersebut berbeda dengan komponen yang harusnya ada. Komponen silabus pembelajaran Tahsin AI-Quran yang dipakai di SD Istiqamah Kota Bandung yaitu mengacu kepada buku tilawati yang dipegang oleh guru pengajar Tahsin Al-Quran maupun yang dipakai oleh siswa. Didalamnya terdapat beberapa komponen yaitu: kompetensi dasar, materi pembelajaran, kegiatan pembelajaran, indikator, penilaian, alokasi waktu, sumber/bahan ajar.

Pada hakikatnya penyusunan RPP bertujuan merancang pengalaman belajar siswa untuk mencapai tujuan pembelajaran. Pentingnya membuat RPP yaitu dapat menolong guru untuk memikirkan pelajaran sebelum pelajaran itu diajarkan sehingga kesulitan belajar dapat diramalkan dan jalan keluarnya dapat dicari. Guru dapat mengorganisasi fasilitas, perlengkapan, alat bantu pengajaran, waktu dan isi dalam rangka untuk mencapai tujuan belajar seefektif mungkin serta menghubungkan tujuan dan prosedur kepada tujuan keseluruhan dari mata pelajaran yang diajarkan (Mahmudah, 2016, hlm. 2-3).

Metode pembelajaran digunakan oleh guru untuk mewujudkan suasana belajar dan proses pembelajaran agar peserta didik mencapai kompetensi dasar atau seperangkat indikator yang telah ditetapkan. Pemilihan metode pembelajaran disesuaikan dengan situasi dan kondisi peserta didik, serta karakteristik dari setiap indikator dan kompetensi yang hendak dicapai pada setiap mata pelajaran (Haerana, 2016, hlm. 41). Metode tilawati merupakan salah satu metode yang digunakan dalam pembelajaran Al-Quran. Adapun yang dimaksud dengan metode tilawati adalah suatu sistem atau cara yang mengatur tentang pembacaan ayat Al-Quran dengan baik dan indah. Metode tilawati merupakan metode belajar membaca Al-Quran yang disampaikan secara seimbang antara pembiasaan melalui pendekatan klasikal dan kebenaran membaca melalui pendekatan individual dengan teknik baca simak (Hasan dkk., 2010, hlm. 16). 
Metode tilawati merupakan metode yang digunakan dalam pembelajaran Al-Quran. Yang memakai sistem atau cara mengatur tentang pembacaan (ayat Al-Quran) dengan baik dan indah (Hasan dkk., 2010). Metode tilawati merupakan metode belajar membaca Al-Quran yang disampaikan secara seimbang antara pembiasaan melalui pendekatan klasikal dan kebenaran membaca melalui pendekatan individual dengan teknik baca simak sesuai dengan yang diterapkan di SD Istiqamah Kota Bandung.

Metode yang diterapkan dalam proses belajar mengajar sangat berpengaruh terhadap perkembangan pembelajaran siswa, dengan nyaman dan mudah dimengerti membuat siswa mudah paham terhadap apa yang dipelajarinya. Metode yang digunakan oleh guru pengajar Tahsin Al-Quran di SD Istiqamah Kota Bandung yaitu menggunakan metode Tilawati. Terdapat tiga langkah dalam tehnik baca simak metode tilawati, yaitu pertama guru membaca siswa mendengarkan, kedua guru membaca siswa menirukan, dan yang ketiga yaitu guru dan siswa membaca bersama-sama (Hasan dkk., 2010)

\section{Pelaksanaan Pembelajaran Tahsin Al-Quran Metode Tilawati di SD Itiqomah Kota Bandung}

Pelaksanaan pembelajaran meliputi pengelolaan kelas, kegiatan pembelajaran yang terdiri atas pendahuluan, kegiatan inti, dan kegiatan penutup. Pengelolaan kelas terdiri atas beberapa hal, yaitu: (1) pengaturan tempat duduk, (2) volume dan intonasi suara guru dalam proses pembelajaran harus dapat didengar dengan baik oleh peserta didik, (3) tutur kata guru santun dan dapat dimengerti oleh peserta didik, (4) guru menyesuaikan materi pelajaran dengan kecepatan dan kemampuan belajar peserta didik, (5) guru menciptakan ketertiban, kedisiplinan, kenyamanan, keselamatan dan keputusan pada peraturan dalam menyelenggarakan proses pembelajaran, (6) guru memberikan penguatan dan umpan balik terhadap respon dan hasil belajar peserta didik selama proses pembelajaran berlangsung, (7) guru menghargai pendapat peserta didik, (8) guru memakai pakaian yang sopan, bersih dan rapi, (9) pada tiap awal semester, guru menyampaikan silabus mata pelajaran yang diampunya, (10) guru memulai dan mengakhiri proses pembelajaran sesuai dengan waktu yang dijadwalkan (Haerana, 2016, hlm. 62).

Adapun pengelolaan kelas di SD Istiqamah Kota Bandung merupakan upaya yang dilakukan guru untuk menciptakan suasana kelas agar tetap kondusif selama pembelajaran. Sebelum proses pembelajaran dimulai, kelas yang diampu sudah dikelompokkan berdasarkan kemampuan siswa agar memudahkan dalam pencapaian target. Pelaksanaannya guru dipandu oleh Standar Operasional Prosedur (SOP) yang di dalamnya diatur bagaimana seorang guru harus bersikap dan tata tertib pelaksanaan pembelajaran Tahsin Al-Quran. Pakaian apa yang harus dipakai oleh guru, bagaimana menghadapi siswa yang terlambat, siswa yang gaduh, dan yang tidak membawa buku tilawati. Di dalam SOP di jelaskan sanksinya masing-masing.

Kegiatan pendahuluan dalam proses pembelajaran terdiri atas: (1) menyiapkan peserta didik secara psikis dan fisik untuk mengikuti proses pembelajaran, (2) mengajukan pertanyaan-pertanyaan yang mengaitkan pengetahuan sebelumnya dengan materi yang akan dipelajari, (3) menjelaskan tujuan pembelajaran atau kompetensi dasar yang akan dicapai, (4) 
menyampaikan cakupan materi dan penjelasan uraian kegiatan sesuai silabus (Haerana, 2016, hlm. 62).

Kegiatan pendahuluan di SD Istiqamah Kota Bandung adalah seorang guru atau pengajar Tahsin Al-Quran akan membuka pembelajaran yang biasanya dengan mengucapkan salam kepada siswa, kemudian menyiapkan siswa agar pembelajaran dapat berlangsung kondusif, setelah itu membaca doa sebelum belajar agar dimudahkan dalam belajar dan diberikan kepahaman ketika belajar, kemudian mengkondisikan siswa agar pelaksanaan proses belajar mengajar efektif dan efisien.

Setelah adanya pembukaan, guru membacakan daftar hadir siswa, bagi siswa yang hadir mengangkat tangannya lulu mengucapkan "hadir" dan bagi siswa yang tidak hadir dijelaskan alasan beserta keterangannya. Guru memberikan motivasi kepada siswa sebelum memulai proses pembelajaran. Ini bermaksud agar siswa tetap memiliki semangat dalam belajar membaca AlQuran. Motivasi ini diperlukan mengingat kondisi seseorang tidak selalu stabil, baik kondisi fisik (kesehatan tubuh) maupun psikis (semangat).

Setelah guru memberikan motivasi, kemudian guru memimpin murojaah (mengulang bacaan) bersama. Murojaah ini bisa mengulang materi tahsin atau tahfizh yang telah dibahas pada pertemuan sebelumnya, tujuannya agar bacaan siswa lebih lancar dan fasih dalam pelafalannya. Kegiatan murojaah ini merupakan kegiatan mengaitkan pembelajaran sebelumnya dengan pembelajaran sekarang (Haerana, 2016). Setelah itu guru menyampaikan cakupan materi dan menjelaskan materi yang akan dibahas sesuai silabus. Dalam kegiatan pendahuluan ini, yang tidak dilakukan adalah menjelaskan tujuan pembelajaran atau kompetensi dasar yang akan dicapai.

Kegiatan inti dalam proses pembelajaran Tahsin terdiri dari eksplorasi, elaborasi, dan konfirmasi sesuai dengan yang telah diterapkan di SD Istiqamah Kota Bandung. Eksplorasi diartikan kegiatan untuk memperoleh pengalaman baru dari situasi yang baru. Terkait dengan proses pembelajaran, kegiatan eksplorasi adalah kegiatan yang dilakukan siswa/siswa guna mendapatkan pengalaman baru di bawah bimbingan guru.

Kegiatan inti dalam pembelajaran Tahsin Al-Quran adalah guru mengarahkan siswa dengan menggunakan metode tilawati sebagai metode pembelajaran yang dipakai di SD Istiqamah Kota Bandung. Guru memberikan keleluasaan tempat bagi siswa untuk belajar membaca AI-Quran. Selama masih dalam lingkungan tempat yang diizinkan. Ruangan yang digunakan dalam pembelajarannya adalah kelas, perpustakaan, laboratorium, masjid, plaza dan taman. Siswa hanya dizinkan untuk berada dilingkungan tempat tersebut. Masing-masing guru tilawati memiliki tempat belajarnya.

Selama waktu pembelajaran, siswa difokuskan untuk membaca Al-Quran dan memperhatikan arahan dari guru pengajarnya agar mencapai target yang telah ditentukan. Karena target tiap siswa berbeda-beda. Penggunaan alat peraga ketika pembelajaran sangat diperlukan dan dipakai karena mempermudah siswa memahami bacaan Al-Quran. Selama proses pembelajaran guru terus memantau dan mengontrol siswa agar tetap kondusif dalam proses belajar.

Kegiatan elaborasi pada proses pembelajaran adalah kegiatan siswa/siswi dalam menyelesaikan tugas-tugas untuk menguasai suatu 
kompetensi secara tekun dan cermat di bawah bimbingan guru. Elaborasi dalam pembelajaran Tahsin adalah jika bacaan siswa dianggap belum memenuhi standar bacaan yang baik, maka guru akan memanggil siswa tersebut dan melakukan pembelajaran khusus kepadanya secara individual ataupun melakukan jam tambahan belajar tahsin dan tilawati diluar jam pelajaran. Apabila masih belum memenuhi standar bacaan, guru memberikan saran kepada orang tuanya agar memberikan pelajaran tambahan seperti les mengaji atau belajar mengaji dirumahnya. Begitupun dengan siswa yang cepat paham dan baik dalam bacaannya akan langsung dimasukan ke kelas Tahfidz Al-Quran. Ini bertujuan agar bacaan siswa benar-benar berkualitas.

Kegiatan konfirmasi dalam pembelajaran adalah kegiatan yang dilakukan guru bersama-sama dengan siswa dalam rangka penegasan, pengesahan, atau pembenaran hasil eksplorasi dan elaborasi. Konfirmasi dalam pembelajaran Tahsin Al-Quran adalah guru memberi penguatan atas apa yang telah dipelajari siswanya atau memberi arahan jika bacaan siswa belum memenuhi standar kelayakan. Jika bacaan siswa lancar dan fasih sesuai kaidah tajwid, serta sudah memenuhi standar kelayakan, maka siswa dianjurkan untuk dimasukan tingkatannya ke kelas Tahfidz Al-Quran. Dan siswa yang cepat dalam pembacaannya akan diberikan reward (hadiah) dari guru pengajar tahsin tilawati.

Kegiatan penutup merupakan rangkaian kegiatan yang dilakukan setelah kegiatan inti pembelajaran dilakukan atau dengan kata lain kegiatan ini adalah akhir dari pembelajaran. Pada tahap ini, seorang guru bersama-sama dengan siswa dan/atau sendiri membuat rangkuman/simpulan pelajaran, melakukan penilaian dan/atau refleksi terhadap kegiatan yang sudah dilaksanakan secara konsisten dan terprogram, memberikan umpan balik terhadap proses dan hasil pembelajaran, merencanakan kegiatan tindak lanjut, menyampaikan rencana pembelajaran pada pertemuan berikutnya (Haerana, 2016, hlm. 69).

Kegiatan penutup pembelajaran Tahsin AI-Quran di SD Istiqamah Kota Bandung dilakukan dengan semua siswa kembali kumpul ke tempat belajar dengan rapih kemudian guru memerintahkan sisiwa untuk mengulang bacaan yang telah dipelajari secara bersama-sama dan menyampaikan kembali apa yang telah dipelajari sebelumnya secara keseluruhan. Mengevaluasi siswa selama pembelajaran berlangsung dan memotivasi siswa untuk terus belajar dengan semangat agar target bacaan siswa tercapai dan lanjut ke jilid berikutnya bahkan bisa lanjut ke kelas Tahfidz Al-Quran. Setelah semua tersampaikan guru memerintahkan siswa untuk berdoa selesai belajar bersama-sama kemudian mengucapkan salam. Meski sudah baik namun ada beberapa yang tidak sesuai dengan kegiatan apa saja yang harus dilakukan dalam kegiatan penutup.

\section{Penilaian Pembelajaran Tahsin Al-Quran Metode Tilawati di SD Istiqomah Kota Bandung}

Dalam penilaian pembelajaran yang harus dilakukan antara lain menyusun rencana evaluasi hasil belajar, yang terdiri atas: (1) merumuskan tujuan dilaksanakannya evaluasi, (2) menetapkan aspek-aspek yang akan dievaluasi, misalnya apakah aspek kognitif, aspek afektif, ataukah aspek psikomotorik, (3) memilih dan menentukan teknik yang akan dipergunakan di dalam pelaksanaan evaluasi, misalnya apakah evaluasi itu akan dilaksanakan dengan teknik tes atau teknik non tes, (4) menyusun alat-alat pengukur yang 
akan digunakan dalam pengukuran dan penilaian hasil belajar siswa, (5) menentukan tolak ukur, norma atau kriteria yang akan dijadikan pegangan atau patokan dalam memberikan interpretasi terhadap data hasil evaluasi, (6) menentukan frekuensi dari kegiatan evaluasi hasil belajar itu sendiri (Haerana, 2016).

Pada tingkat satuan pendidikan, komponenen penilaiannya dikenal dengan Penilaian Berbasis Kelas. Didalamnya terdapat proses pengumpulan, pelaporan dan penggunaan informasi tentang belajar siswa yang diperoleh melalui pengukuran untuk menganalisis atau menjelaskan hasil kerja atau prestasi siswa dalam mengerjakan tugas-tugas terkait. Proses penilaian mencakup pengumpulan sejumlah bukti-bukti yang menunjukan pencapaian hasil belajar siswa (Majid, 2014, hlm. 313).

Penilaian pembelajaran Tahsin AI-Quran di SD Istiqamah Kota Bandung dimulai dengan menyusun rencana evaluasi hasil belajar. Tujuan evaluasi adalah untuk mengukur ketercapaian target siswa dan membandingkan capaian siswa saat ini dengan sebelumnya. Aspek-aspek yang akan dievaluasi disusun berdasarkan syarat kenaikan kelas siswa dan selama berjalannya program pembelajaran, teknik, alat-alat yang digunakan, tolak ukur dan frekuensi direncanakan diawal dan disepakati bersama.

Setelah membuat rencana evaluasi yang harus dilakukan berikutnya adalah menghimpun data, melakukan verifikasi data, mengolah dan menganalisis data, memberikan interpretasi dan menarik kesimpulan, serta tindak lanjut hasil evaluasi. Menghimpun data penilaian dilakukan setiap hari. Selanjutnya data harian ini diolah untuk dijadikan data dalam penilaian tengah semester dan akhir semester. Hasil belajar siswa akan dianalisis dan diinterpretasi bersama pada rapat guru. Dari hasil analisis dan interpretasi tersebut maka akan muncul kesimpulan dan tindak lanjut. Tindak lanjut yang dilakukan oleh guru SD Istiqamah Kota Bandung biasanya bersifat persuasif. Yakni membuat pendekatan dengan siswa untuk menggali informasi apa yang menyebabkan hasil belajarnya lebih baik dari kemarin atau lebih buruk dari kemarin.

Laporan kemajuan hasil belajar pada dasarnya mencakup semua pencapaian siswa dalam hal penguasaanya terhadap setiap indikator kompetensi yang telah dipelajarinya, sehingga dengan data tersebut setiap siswa akan dapat diukur tingkat keberhasilannya ataupun juga tingkat kegagalannya. Dan informasi tentang pencapaian hasil belajar itu akan mengarahkan strategi pembelajaran apa yang harus dilakukan oleh guru untuk dapat memberikan kesempatan kembali kepada siswa agar bisa memperbaiki nilai yang diperolehnya.

Laporan hasil belajar siswa di SD Istiqamah Kota Bandung disusun dalam bentuk laporan penilaian harian berbentuk lembaran pegangan guru Tahsin AlQuran tilawati, kemudian laporan tersebut direkap kedalam raport hasil belajar siswa selama tengah semester sekaigus hasil nilai munaqasyah tengah semester. Laporan penilaian akhir semester merupakan rekapitulasi dari penilaian harian, penilaian tengah semester dan akhir semester disatukan dan dijumlahkan berdasarkan kemajuan hasil belajar siswa selama satu semester atau satu tahun. Laporan-laporan kemajuan hasil belajar tersebut dilaporkan kepada siswa, sekolah, dan orang tua siswa. 


\section{Faktor Pendukung dan Penghambat Tahsin Al-Quran Metode Tilawati di SD Istiqomah Kota Bandung}

Setidaknya terdapat tiga faktor pendukung dan penghambat dalam pembelajaran Tahsin Al-Quran yakni faktor guru, siswa, dan sarana dan prasarana (Haerana, 2016). Pembelajaran Tahsin Al-Quran metode tilawati di SD Istiqamah Kota Bandung didukung oleh guru pengajar Tahsin Al-Quran yang menguasai konsep strategi pembelajarn Al-Quran metode tilawati yang terdapat dalam buku acuan pembelajaran Tahsin Al-Quran. Namun sebagian guru juga menjadi faktor penghambat disebabkan tidak semua guru menerapkan sistem pengajarannya di kelas. Seperti guru yang mengajarkan mata pelajaran Tahsin Al-Quran tidak sesuai dengan silabus, bahkan tidak membuat RPP ketika sebelum proses belajar mengajar berlangsung. Siswa juga menjadi faktor pendukung karena memiliki motivasi yang tinggi serta mendapat dukungan dari keluarga. Namun sebagian siswa lainnya menjadi faktor penghambat disebabkan kurangnya motivasi dan mempengaruhi yang lainnya. Sarana prasarana di SD Istiqamah Kota Bandung secara umum memadai dalam mendukung pembelajaran Tahsin Al-Quran metode tilawati. Namun terdapat faktor penghambat disebabkan kurangnya ruangan kelas membuat siswa belajar di tempat-tempat yang ada di sekitarnya seperti taman, perpustakaan, laboratorium dan plaza.

\section{Hasil Pembelajaran Tahsin Al-Quran Metode Tilawati di SD Istiqomah Kota Bandung}

Hasil belajar adalah seluruh kecakapan dan hasil yang dicapai melalui proses belajar mengajar di sekolah yang dinyatakan dengan angka-angka atau nilai-nilai berdasarkan tes hasil belajar. Sedangkan Jenkins dan Unwin mengatakan bahwa hasil belajar adalah pernyataan yang menunjukkan tentang apa yang mungkin dikerjakan siswa sebagai hasil dari kegiatan belajarnya (Uno, 2012). Adapun hasil yang ingin dicapai dalam pembelajaran Tahsin Al-Quran di SD Istiqamaha Kota Bandung yaitu mencetak generasi Qurani yang beriman, berilmu dan berakhlak mulia, menjadikan anak didik SD Istiqamah Kota Bandung pandai dalam membaca Al-Quran sesuai dengan kaidah ilmu tajwid dan di tahun yang akan datang target lulusan SD Istiqamah Kota Bandung bisa hafal minimal 2 juz Al-Quran.

Hasil di atas merupakan buah dari konsep yang telah dibuat dengan sungguh-sungguh diawal, pelaksanaan yang sesuai konsep perencanaan, serta komitmen dari seluruh civitas sekolah. Pengakuan dari seorang siswa, diawalawal belajar di SD Istiqamah Kota Bandung, pada tahun pertama dan kedua siswa mampu membaca huruf hijaiyah dan lancar membaca bacaan panjang dan pendek 2 harokat ( $m a d$ ). Ditahun ketiga dan keempat siswa mampu membaca huruf-huruf sukun serta fasih membaca menggunakan irama rost. Dan ditahun kelima dan keenam siswa menguasai tajwid dan fasih membaca menggunakan irama rost.

Perbedaan-perbedaan pencapaian siswa dalam membaca Al-Quran disebabkan banyak faktor. Menurut Koordinator Tahsin Al-Quran metode tilawati SD Istiqamah Kota Bandung, ada tiga faktor yang mempengaruhi perbedaan siswa dalam membaca Al-Quran. Pertama, kemampuan siswa berbeda-beda. 
Ada yang cepat lancar dalam membacanya, ada pula yang lambat. Kedua, waktu masuk ke SD Istiqamah Kota Bandung. Mengingat di SD Istiqamah Kota Bandung ada jenjang TK dan SD, namun dalam pembelajaran tahsin AI-Quran sudah diterapkan di TK Istiqamah Kota Bandung, bagi siswa yang dulu alumni sekolah di TK Istiqamah Kota Bandung sudah terbilang lancar dalam pembelajaran tahsin Al-Quran tentang SD, maka rata-rata langsung melanjutkan ke tahap tahfidz AI-Quran.

\section{SIMPULAN}

Kegiatan perencanaan pembelajaran Tahsin Al-Quran metode Tilawati di SD Istiqamah Kota Bandung dilakukan dengan membuat konsep pembelajaran yang dirinci dengan perencanaan jangka pendek, jangka menengah, dan jangka panjang. Konsep ini disusun sendiri oleh Kepala Sekolah SD Istiqamah Kota Bandung yaitu Sunda Hadi, S.Pd. Perencanaan pembelajaran dalam operasional dikonkretkan dalam bentuk silabus dan Rencana Pelaksanaan Pembelajaran (RPP). Silabus dibuat untuk jadi acuan bersama sehingga tidak ada perubahan atau modifikasi. Sedangkan RPP harus dibuat oleh guru pengajar Tahsin AlQuran sebelum pelaksanaan pembelajaran dimulai. Kegiatan pelaksanaan pembelajaran Tahsin Al-Quran metode Tilawati dilakukan dengan pengelolaan kelas yang baik. Kegiatan pembelajaran dimulai dengan kegiatan pembukaan seorang guru mengawali pembelajaran dengan mengucapkan salam kepada siswa, kemudian menyiapkan siswa agar pembelajaran dapat berlangsung kondusif, setelah itu membaca doa sebelum belajar agar dimudahkan dalam belajar dan diberikan kepahaman ketika belajar, kemudian mengkondisikan siswa agar pelaksanaan proses belajar mengajar efektif dan efisien. Kegiatan inti dalam pembelajaran berisi tentang eksplorasi, elaborasi, dan konfirmasi. Eksplorasi dalam pembelajaran Tahsin Al-Quran adalah guru mengajarkan siswa menggunakan metode Tilawati sesuai dengan kemampuan siswa. Kemudian ditempatkan sesuai klasifikasi kemampuan siswa tersebut. Elaborasi dalam pembelajaran Tahsin AI-Quran di SD Istiqamah Kota Bandung jika metode tilawati yang dilakukan dengan baca simak telah selesai dalam 8 kali putaran, maka siswa membaca bersama-sama dan dites oleh guru satu persatu. Dan konfirmasi dalam pembelajaran Tahsin Al-Quran adalah guru memberi penguatan atas apa yang telah dibaca siswanya dan memberi arahan jika bacaan siswa belum memenuhi standar kelayakan.

Kegiatan penilaian pembelajaran Tahsin Al-Quran metode Tilawati disusun dalam bentuk laporan penilaian harian berbentuk lembaran pegangan guru Tahsin Al-Quran metode Tilawati, kemudian laporan tersebut direkap kedalam raport hasil belajar siswa selama tengah semester sekaigus hasil nilai munaqasyah tengah semester. Laporan penilaian akhir semester merupakan rekapitulasi dari penilaian harian, penilaian tengah semester dan akhir semester disatukan dan dijumlahkan berdasarkan kemajuan hasil belajar siswa selama satu semester atau satu tahun. Faktor pendukung pembelajaran Tahsin Al-Quran metode Tilawati diantaranya adalah santri yang didukung oleh keluarga, oleh guru pengajar Tahsin Al-Quran yang menguasai konsep strategi pembelajarn AlQuran metode Tilawati yang terdapat dalam buku acuan pembelajaran Tahsin AI-Quran, Sarana prasarana di SD Istiqamah Kota Bandung secara umum memadai dalam mendukung pembelajaran Tahsin Al-Quran metode Tilawati. 
Sedangkan faktor penghambat pembelajaran Tahsin Al-Quran metode Tilawati adalah sebagian guru tidak menerapkan sistem pengajarannya di kelas, sarana dan prasarana yang kurangnya ruangan kelas membuat siswa belajar di tempattempat yang ada di sekitarnya seperti: taman, perpustakaan, laboratorium dan plaza. Hasil pembelajaran Tahsin Al-Quran metode Tilawati diantaranya SD Istiqamah Kota Bandung pandai dalam membaca Al-Quran sesuai dengan kaidah ilmu tajwid dan di tahun yang akan datang target lulusan SD Istiqamah Kota Bandung bisa hafal minimal 2 juz Al-Quran. Dan pada tahun ajaran ini SD Istiqamah Kota Bandung telah mencetak siswa yang hafal 2 juz Al-Quran.

\section{REFERENSI}

Ariani, S., \& Realita. (2015). Program Bengkel Mengaji (Upaya Peningkatan Kemampuan Tahsin Al-Qur'an Mahasiswa PAI). Jurnal MUDARRISUNA (Media Kajian Pendidikan Agama Islam), 5(1), 113-144. https://doi.org/10.22373/jm.v5i1.301

Badrudin. (2013). Dasar-Dasar Manajemen. Alfabeta.

Badrudin. (2017). Manajemen Pembelajaran Bahasa Arab Berbasis TIK di Madrasah Aliyah Daarul Uluum Majalengka. MANAGERIA: Jurnal Manajemen Pendidikan Islam, 2(1), 155-167. https://doi.org/10.14421/manageria.2017.21-08

Baharuddin. (2012). Metode Pembelajaran IImu Tajwid dalam Meningkatkan Kemampuan Membaca Al-Qur'an Santri Pondok Pesantren Tahfizh AlQur'an Al-Imam 'Ashim Makassar [Thesis, Universitas Islam Negeri Alauddin]. alauddin.ac.id/5672/1/Tesis\%20Baharuddin.pdf

Haerana. (2016). Manajemen Pembelajaran Berbasis Standar Proses Pendidikan (Teori dan Aplikasinya). Media Akademi.

Hasan, A., Arif, M., \& Rouf, A. (2010). Strategi Pembelajaran Al-Quran Metode Tilawati (Tingkat dasar Tilawai dan Tingkat Lanjutan Al-Quran). Pesantren Al-Quran Nurul Falah.

Jahari, J. (2013). Manajemen Madrasah. Alfabeta.

Mahmudah, T. (2016). Penyusunan Rencana Pelaksanaan Pembelajaran (RPP) Guru Bahasa Indonesia di SMP Negeri 2 bantul. E-Journal Pendidikan Bahasa dan Sastra Indonesia, 1-11.

Mahmuddin, I. (2013). Tinjauan Terhadap Perencanaan dan Strategi Pembelajaran Materi Substansi Al_Quran pada Sekolah Dasar Kelas 1 Semester 2. Makalah Perencanaan dan Strategi Pembelajaran. http://syamsmahmoed.blogspot.com/2013/01/makalah-perencanaandan-strategi.html

Majid, A. (2014). Belajar dan Pembelajaran (Pendidikan Agama Islam). PT Remaja Rosdakarya.

Nurkarima, R. (2015). Analisis Pengelolaan Pembelajaran Tahsin dan Tahfidz AlQuran dengan Metode Talaqqi di Kelas VIII SMPIT Qordova Rancaekek Bandung. Prosiding Pendidikan Agama Islam, 1(2), 163-173.

Supiani, E., Murniati, \& Usman, N. (2016). Implementasi Manajemen Pembelajaran Al-Qur'an di Sekolah Dasar Islam Terpadu Nurul Ishlah Banda Aceh. Jurnal Pencerahan, 10(1), 39-47. https://doi.org/10.13170/jp.10.1.4873 
H. Khoiruddin, A. W. Kustiani

Suryana, Y., Dian, D., \& Nuraeni, S. (2019). Manajemen Program Tahfidz AlQuran. Jurnal Isema: Islamic Educational Management, 3(2), 103-113. https://doi.org/10.15575/isema.v3i2.5014

Terry, G. R. (2013). Prinsip-Prinsip Manajemen. Bumi Aksara.

Thomas, P. (2011). Manajemen Pembelajaran di SMK Negeri 2 Semarang. Jurnal Dinamika Pendidikan, 6(1), 15-25. https://doi.org/10.15294/dp.v6i1.5344

Triwiyanto, T. (2015). Manajemen Kurikulum dan Pembelajaran. Bumi Aksara. Uno, H. B. (2012). Perencanaan Pembelajarn. Bumi Aksara. 